\title{
INTERCULTURAL COMPETENCE PROFILES IN RUSSIAN UNIVERSITY STUDENTS
}

\author{
Irina A. Novikova ${ }^{1}$, Alexey L. Novikov' ${ }^{1}$, Marina V. Gridunova ${ }^{1}$, \\ Gulnara N. Zamaldinova ${ }^{2}$ \\ ${ }^{1}$ Peoples' Friendship University of Russia (RUDN University) \\ Miklukho-Maklaya str., 6, Moscow, Russia, 117198 \\ ${ }^{2}$ National University of Science and Technology MISiS \\ Leninskiy prospekt, 4, Moscow, Russia, 119991
}

The article is devoted to the study of intercultural competence (ICC) as a psychological phenomenon including the analysis of its models, factors, and profiles. The results of an empirical study in two major multinational Russian universities (388 students, of which 254 young women and 134 young men) are presented. The aim of the study was to identify the typological profiles of the ICC and their characteristics in relation to personality traits. ICC was studied based on the "Dynamic model of intercultural sensitivity" by M. Bennet. The author's modification of the "Scale of intercultural sensitivity" by O.E. Khuhlaev and M.Y. Chibisova in the adaptation of Y.A. Lopashenko was used for the ICC diagnostics. Personality traits were considered in the framework of the Five-Factor Model (P. Costa and R. McCrae) and were measured by a short form of the "Five-Factor Questionnaire" in Russian adaptation by M.V. Bodunov and S.D. Biryukov. We identified four ICC profiles of students provisionally called "ethnocentrists", "negativists", "undecided (ambivalent)", and "ethnorelativists". It is shown that the profiles differ not only in the correlation between the severity of parameters of the ICC, but also in personality traits. The results can be used for the design of ICC development and formation programs, based on the identified psychological specifics of ICC profiles.

Key words: intercultural competence, intercultural sensitivity, intercultural competence profiles, Big Five factors, personality traits, Five-Factor Model

\section{Introduction}

Harsh socio-political and economic changes occurring in the world and in Russia in recent years are leading to an increase in international tension, aggravation of interethnic, inter-confessional and intercultural conflicts. Intercultural competence (ICC) is one of the recognized means of preventing and solving intercultural conflicts. ICC diagnostics, as well as opportunities for its development and formation are an important subject for scientific discussion. At the same time, the difficulties of studying the problem of ICC and related constructs are determined by the lack of a common understanding of these phenomena and, accordingly, their reliable diagnostic methods.

\section{Problems of intercultural competence research}

Today, there is no universally accepted scientific approach to the definition, structure and measurement of ICC as a psychological construct. Russian and foreign scientists 
have developed more than 60 ICC models (Chernyak, 2015). Wherein, the authors of these models use a number of similar concepts, such as intercultural competence (Borghetti, 2013; Chibisova, \& Khukhlaev, 2008; Deardorff, 2006; Sinicrope et al., 2013 and etc.), intercultural communicative competence (Byram, 1997; Skopinskaja, 2009 and etc.), intercultural sensitivity (Bennett, 1986, 1993; Hammer et al., 2003; Pochebut, \& Logashenko, 2014 and etc.), multicultural effectiveness (Van der Zee, \& Van Oudenhoven, 2014 and etc.) and some others. The ICC concept, in our opinion, is not only the most frequently studied, but also the broadest of the listed above. Therefore, in this article we will use the term intercultural competence (ICC) in the broadest sense, as a generalizing designation of the phenomenon characterizing the personality activity in a multicultural space towards to different aspects of intercultural diversity and dialogue.

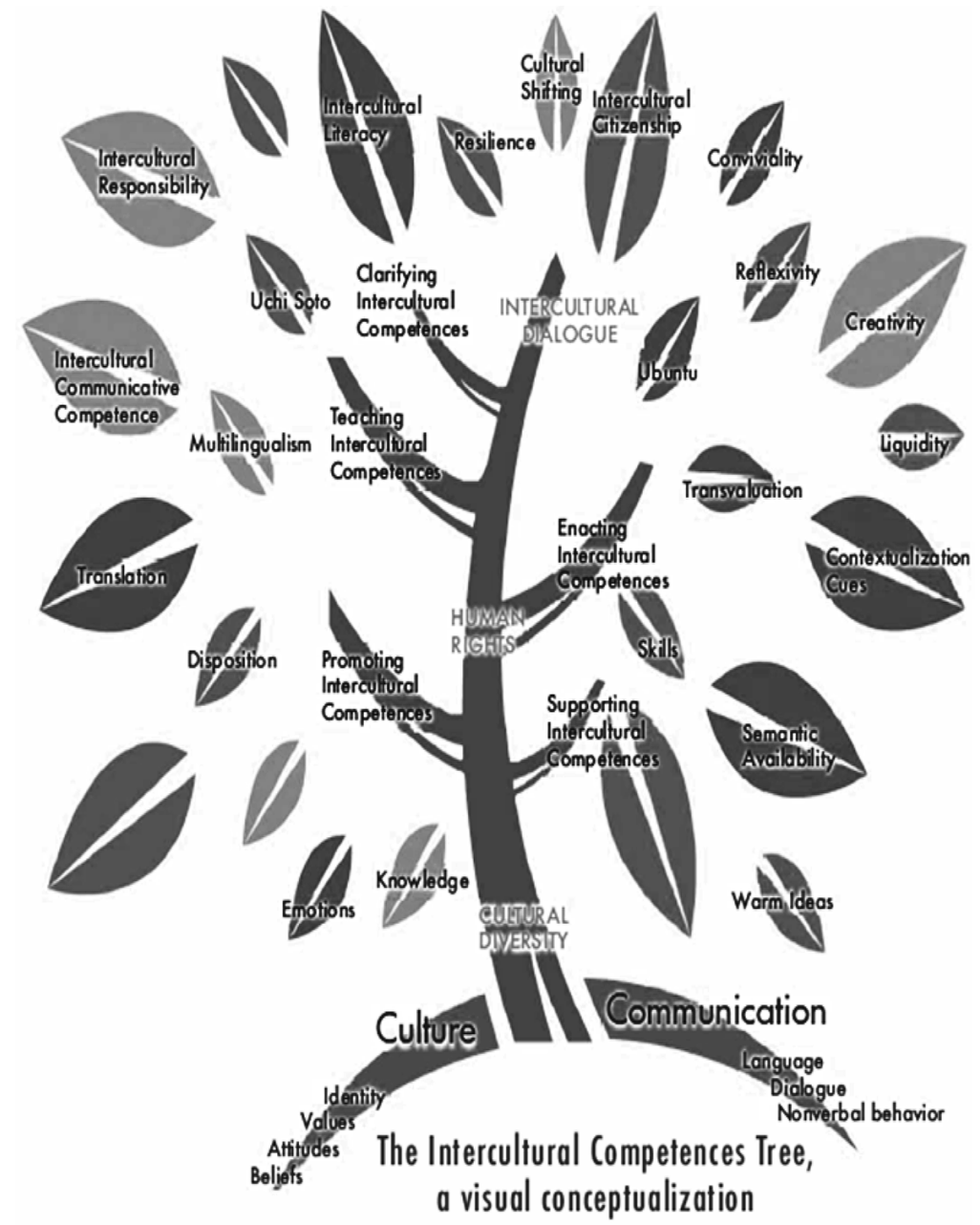

Fig. 1. Intercultural Competence Tree by UNESCO (UNESCO, 2013: 23)

Summarizing the different approaches to the study of the ICC problem, UNESCO experts suggested the "Intercultural Competences Tree" as an attempt to suggest a symbolic view of intercultural competences as an organic system of concepts (UNESCO, 2013, p. 22-24). The Tree (see Fig. 1) has Culture (Identity, Values, Attitudes, Beliefs, 
etc.) and Communication (Language, Dialogue, Nonverbal behavior, etc.) as its roots, Cultural Diversity, Human Rights and Intercultural Dialogue as its trunk; and five operational steps as the branches (Clarifying, Teaching, Promoting, Supporting, and Enacting Intercultural Competences). The leaves (Intercultural Responsibility, Intercultural Literacy, Resilience, Cultural Shifting, Intercultural Citizenship, Conviviality, Reflexivity, Creativity, Liquidity, Contextualization Cues, Transvaluation, Ubuntu, Semantic Availability, Warm Ideas, Skills, Uchi Soto, Multilingualism, Disposition, Emotions, Knowledge, Translation, Intercultural Communicative Competence) represent the various manners in which the intercultural competences can be understood or articulated in concrete contexts. The authors of visualization note that "some of the leaves have been left free so that this Tree which is very much alive, can be complemented upon the rich diversity of contexts available worldwide" (UNESCO, 2013: 23).

\section{Developmental Model of Intercultural Sensitivity and its Russian adaptation}

Milton J. Bennett $(1986,1993)$ posited a framework for conceptualizing dimensions of ICC in his Developmental Model of Intercultural Sensitivity (DMIS). The DMIS constitutes a progression of worldview "orientations toward cultural difference" that comprise the potential for increasingly more sophisticated intercultural experiences. Three ethnocentric orientations, where one's culture is experienced as central to reality (Denial, Defense, Minimization), and three ethnorelative orientations, where one's culture is experienced in the context of other cultures (Acceptance, Adaptation, Integration), are identified in the DMIS (Hammer, Bennett, \& Wiseman, 2003, p. 421). Based on this theoretical framework, the Intercultural Development Inventory (IDI) was constructed to measure the orientations toward cultural differences described in the DMIS (Hammer, Bennett, Wiseman, 2003).

Russian psychologists O.E. Khukhlaev and M.Y. Chibisova (Chibisova, \& Khukhlaev, 2008) developed a Russian-language technique for ICC diagnostics based on the DMIS, that has been tested in a number of studies (Gridunova, Novikova, \& Shlyakhta, 2017; Logashenko, 2015; Pochebut, \& Logashenko, 2014). This technique, called the "Intercultural Sensitivity Scale", includes 4 subscales:

1) Minimization (the orientation to assess cultural differences as insignificant in the interaction);

2) Absolutization (the orientation to assess cultural differences as uncontrollable in intercultural interaction);

3) Ambivalence (the orientation, which reflects the degree of consistency and harmony of attitudes towards cultural differences);

4) Acceptance (the orientation to recognize and notice cultural differences and take them into account in intercultural interaction).

Minimization and Absolutization correspond to ethnocentric orientations according to the DMIS. Ambivalence is a transitional orientation from ethnocentrism to ethnorelativism. Acceptance corresponds to ethnorelative orientations according to the DMIS (Logashenko, 2015).

Based on the DMIS and using for diagnostic the "Intercultural Sensitivity Scale", Y.A. Logashenko (Logashenko, 2015) proposed the Intercultural Sensitivity Model that includes three components: 
1) the ability to notice and recognize cultural differences, which is measured using the Acceptance subscale (high Acceptance rates);

2) the ability to assess the impact of cultural differences in intercultural communication, which is measured using the Minimization subscale (low Minimization rates);

3 ) the ability to assess the possibility to control the impact of cultural differences on intercultural dialogue, which is diagnosed using the Absolutization subscale (low Absolutization rates).

The author believes that various combinations of these components expression allow to construct four intercultural sensitivity profiles: moderate, balanced, extreme and contradictory. Moderate profile corresponds to low expression of all components, balanced profile - to medium expression of all components, extreme profile - to high expression of all components, and contradictory profile is characterized by different expression of components (Logashenko, 2015). In our opinion, the proposed profile description is too hypothetical and needs to be empirically tested using cluster analysis.

\section{ICC Factors and Predictors}

Numerous empirical studies have found that intercultural competence is associated with a variety of social and psychological factors (Gridunova et al., 2017; Gridunova, Novikova, \& Shlyakhta, 2017; Kornilova, 2012; Logashenko, 2015; Pochebut, \& Logashenko, 2014; Van der Zee, \& Van Oudenhoven, 2013 and etc.). Among social factors, in particular, we can highlight the experience of intercultural interaction, including, among others, study abroad or in multinational universities. A number of Western research on the basis of the DMIS using the IDI shows the positive impact of short-term and long-term abroad training programs on the development of intercultural sensitivity (Anderson et al., 2006; Kehl, \& Morris, 2007-2008; Rexeisen, \& Al-Khatib, 2009 and etc.). Similar conclusions were reached by Y.A. Logashchenko (2014), exploring the Russian sample with a different experience of intercultural communication, and also by M.V. Kornilova (2012), who studied the dynamics of the ICC in mono and multicultural student groups.

ICC psychological factors include, first of all, personality traits and intellectual abilities, which, in turn, can mediate each other. In Western psychology, personal predictors of ICC are most often studied on the basis of the Five-Factor Model (FFM). Studies in different countries show that all FFM personality traits are somehow related to ICC, but there is a specificity of these relationships in different national, age, and professional samples, and also depending on the methods of ICC diagnostics (Huang et al., 2005; Van der Zee, \& Van der Gang, 2007; Van der Zee, \& Van Oudenhoven, 2013; Van der Zee, \& Van Oudenhoven, 2014 and etc.). In turn, S. Yeke and F. Semerciöz (2016), studying the relationship between intercultural communicative competence, the FFM personality traits and cultural intelligence, came to the conclusion that personality traits influence the ICC, but this influence may be less pronounced with higher cultural intelligence. Therefore, according to the authors, cultural intelligence is more significant for the ICC than personality traits (Yeke, \& Semerciöz, 2016).

In Russian psychology, personal factors of intercultural competence were studied by L.G. Pochebut on the basis of the author's concept of intercultural communicative competence (Pochebut, 2012). The author established that the core of intercultural 
communicative competence is interethnic tolerance, in one block with interpersonal tolerance, trust, and sensitivity (empathy).

In studies of the ICC psychological factors, conducted in the samples of Russian university (Gridunova, Novikova, \& Shlyakhta 2017) and high school (Gridunova et al., 2017) students using the "Intercultural Sensitivity Scale", it was found that:

1) most of the FFM personality traits are related to the ICC in Russian university students (Openness and Conscientiousness are associated with the Acceptance of cultural differences, Extroversion and Agreeableness - with the Ambivalence of attitudes toward cultural differences, Agreeableness - with the orientation to Absolutization of cultural differences);

2) FFM personality traits, and above all, Conscientiousness and Extraversion, are related to the ICC in Russian high school students, but these relations vary in groups with different levels of intellectual development. The most significant personality factor of the ICC in high school students with a higher level of intellectual development is Neuroticism (the pole of emotional stability).

Thus, in modern psychology the ICC is studied as a complex phenomenon, which includes different levels, components, stages of development, and also associated with numerous social and psychological factors (for example, personality traits, intellect, attitudes, etc.). Also, researchers suggest the existence of the ICC profiles, characterized by a different ratio of its components or indicators. However, there are no studies in which the ICC profiles would be characterized in relation to personality traits, although this approach has particular practical importance for the purposeful ICC development and measurement.

Accordingly, the purpose of the study presented in this article is to empirically identify the ICC profiles, considered on the basis of DMIS in its Russian adaptation, and their characteristics in relation to the FFM personality traits in Russian university students.

Based on the literature review, we hypothesize that:

1) there are four ICC profiles, which are determined by the relationship and dominance of the orientations toward cultural differences described in the DMIS Russian adaptation by O.E. Khukhlaev and M.Y. Chibisova;

2) each of the ICC profiles is characterized by the specificity of the expression of FFM personality traits.

\section{Methods}

The research was conducted in 2015/16 and 2016/17 academic years on the basis of two major Moscow universities, namely Peoples' Friendship University of Russia (RUDN University) and National University of Science and Technology MISiS. Both universities are among the top 20 of the Russian universities and are participants of the 5-100 Project.

Sampling. A total of 388 students, aged 17 to 24 (the average age is 18.9 years), of them 254 young women and 134 young men, took part in the research. All the respondents were the first, second and third-year students of different departments of RUDN University and MISiS. The students represent different regions of Russia, as well as the republics of the former USSR (Azerbaijan, Armenia, Belarus, Georgia, Kazakhstan, Moldova, Tajikistan, Turkmenistan, Uzbekistan). All of them speak Russian as a native language and study in Russian. They participated in the study during classes in psychological and 
pedagogical disciplines, as one of the additional tasks, for which they received additional points.

Techniques. The "Intercultural Sensitivity Scale" by O.E. Khukhlaev and M.Y. Chibisova (Chibisova and Khukhlaev, 2008) in Y.A. Logashchenko' modification version (Logashchenko, 2015) was applied for revealing ICC features. The original version of this technique contains 51 items, which are grouped into four subscales (Acceptance, Absolutization, Ambivalence, Minimization), described in detail above. But we also have made a number of modifications to this technique:

1) suggested using a direct response scale: from 0 ("totally disagree") to 10 ("absolutely agree");

2) reduced the number of items on each scale to 8 based on a psychometric study using the coefficients Cronbach' $\alpha$ and McDonald's $\omega_{h}$.

Accordingly, in this version of the technique the total scores for each subscale can range from 0 to 80 points.

To measure the FFM traits, a short version of the NEO Five-Factor Inventory was used (Costa, McCrae, 1992). The Russian version of NEO-FFI, the "Five-Factor Inventory" (adapted by S. Biryukov \& M. Bodunov) consists of 60 direct and inverted items to which the subject expresses the degree of consent from the five answer choices (from "strongly disagree" to "strongly agree"). The resulting values for each of the FiveFactor scales (Neuroticism, Extraversion, Openness, Consciousness, and Agreeableness) range from 12 to 60 points (Bodunov, \& Biryukov, 1989). This version of the questionnaire is well tested on different Russian samples (Murzakanova, 2015; Novikova et al., 2016; Vorobyeva, 2015).

The descriptive statistics methods, coefficients Cronbach' $\alpha$ and McDonald's $\omega_{h}$, Spearman rank correlation analysis, cluster analysis (k-means), and Mann-Whitney' U-test were used for processing the data. Statistical processing was carried out in the $R$ software environment for statistical computing and graphics, version 3.3.2 (R Core Team, 2016).

\section{Results and Discussion}

The psychometric test results (Cronbach' $\alpha$ and McDonald's $\omega_{h}$ ), main parameters of descriptive statistics (Mean and Standard Deviation), and the Spearman correlation coefficients between all variables (subscales) of the "Intercultural Sensitivity Scale" (in our modification) are given in Table 1 .

Table 1

Cronbach' alpha coefficients, McDonald's omega coefficients (hierarchical), Means, Standard

Deviations, and Correlations between Variables of the "Intercultural Sensitivity Scale" $(N=388)$

\begin{tabular}{|l|c|c|c|c|l|l|l|}
\hline Variables (Subcales) & $\alpha$ & $\omega_{\boldsymbol{h}}$ & \multicolumn{1}{|c|}{ Mean } & SD & \multicolumn{1}{|c|}{ Acceptance } & Absolutization & Ambivalence \\
\hline Acceptance & .78 & .70 & 55.11 & 12.95 & 1.00 & & \\
\hline Absolutization & .75 & .57 & 34.87 & 14.29 & -.07 & 1.00 & \\
\hline Ambivalence & .71 & .56 & 52.65 & 11.82 & $.51^{\star \star \star}$ & $.24^{\star \star \star}$ & 1.00 \\
\hline Minimization & .67 & .41 & 50.73 & 11.38 & .02 & $-.20^{\star \star \star}$ & $-.13^{\star \star}$ \\
\hline
\end{tabular}

${ }^{\star \star} p<.01,{ }^{* \star \star} p<.001$, two tailed. 
The results given in Table 1 confirm that for all subscales of the "Intercultural Sensitivity Scale" acceptable Cronbach' $\alpha$ coefficients $(0,67-0,78)$ were obtained. While the McDonald's $\omega_{h}$ coefficient values show that for all items of each subscale there are factor loads in modulus greater than $0.2(0.41-0.70)$, which indicates their acceptable internal consistency (Revelle, Zinbarg 2009). Correlations coefficients between the subscales confirm the "Intercultural Sensitivity Scale" theoretical background that Ambivalence is a transitional stage from ethnocentrism to ethnorelativism, and the minimization of cultural differences is opposite to their Absolutization.

The results of the cluster analysis (k-means) of the "Scale of Intercultural Sensitivity" variables are presented in Table 2 and in Fig. 2 . We got a four clusters structure, and the differences between the clusters are valid according to the $F$-test $(p \leq .05)$.

Table 2

The results of the cluster analysis (k-means) of the "Scale of Intercultural Sensitivity" variables

\begin{tabular}{|c|l|l|l|l|l|l|l|}
\hline \multirow{2}{*}{ Cluster } & \multirow{2}{*}{ Profile Name } & \multirow{2}{*}{$N$} & \multirow{2}{*}{$\%$} & \multicolumn{4}{|c|}{ Cluster centers for variables (subscales) } \\
\cline { 5 - 8 } & & & & Acceptance & Absolutization & Ambivalence & Minimization \\
\hline 1 & Ethnocentrists & 108 & 27.83 & 43.76 & 42.16 & 46.42 & 46.26 \\
\hline 2 & Negativists & 61 & 15.72 & 45.28 & 19.34 & 38.89 & 60.46 \\
\hline 3 & Undecided (Ambivalent) & 118 & 30.41 & 62.19 & 46.01 & 61.45 & 49.38 \\
\hline 4 & Ethnorelativists & 101 & 26.04 & 64.90 & 23.43 & 57.37 & 51.23 \\
\hline \multicolumn{2}{r}{ Total sample } & 388 & 100.00 & 55.11 & 34.87 & 52.65 & 50.73 \\
\hline
\end{tabular}

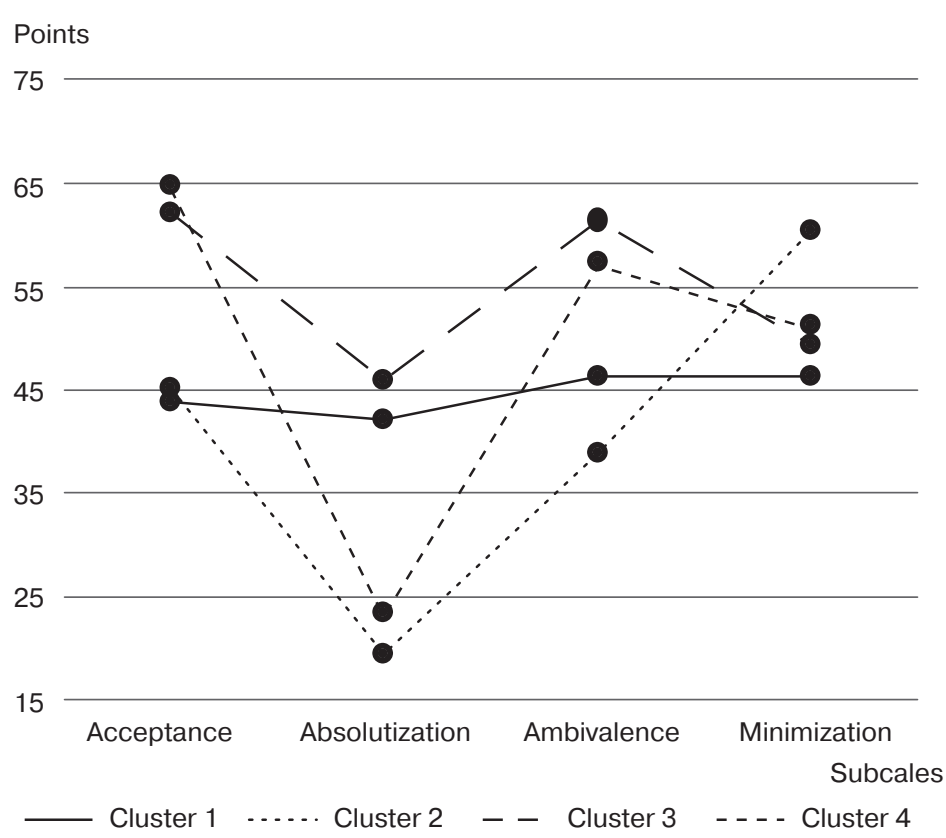

Fig. 2. ICC profiles

As it can be seen in Fig. 2, the ICC profiles obtained as a result of the cluster analysis differ in dominance and relations of the variables. It is reflected in their names (Tabl. 2) and confirms our first hypothesis. As expected, we obtained more complex relationships of ICC variables than those hypothetical profiles described by Y.A. Logashchenko (Logashchenko, 2016). 
For a more detailed psychological characterization, we compared the severity of FFM personality traits in representatives of each ICC cluster (Tabl. 3, 4).

Table 3

FFM personality traits descriptive statistics for each ICC cluster

\begin{tabular}{|l|c|c|c|c|c|c|c|c|c|c|}
\hline \multirow{2}{*}{ Cluster } & \multicolumn{2}{|c|}{ Neuroticism } & \multicolumn{2}{c|}{ Extraversion } & \multicolumn{2}{c|}{ Openness } & \multicolumn{2}{c|}{ Agreeableness } & \multicolumn{2}{c|}{ Consciousness } \\
\cline { 2 - 12 } & Mean & SD & Mean & SD & Mean & SD & Mean & SD & Mean & SD \\
\hline 1 & 35.34 & 4.88 & 39.46 & 5.16 & 36.60 & 3.78 & 39.63 & 5.38 & 39.83 & 5.59 \\
\hline 2 & 35.34 & 4.05 & 39.44 & 4.47 & 35.90 & 3.94 & 37.72 & 4.42 & 40.36 & 4.05 \\
\hline 3 & 34.97 & 4.66 & 40.69 & 4.87 & 36.93 & 3.57 & 39.79 & 4.65 & 41.06 & 4.58 \\
\hline 4 & 34.08 & 5.62 & 40.65 & 5.30 & 37.59 & 5.43 & 39.41 & 5.03 & 41.31 & 4.95 \\
\hline Total & 34.90 & 4.91 & 40.14 & 5.02 & 36.85 & 4.26 & 39.32 & 4.96 & 40.67 & 4.92 \\
\hline
\end{tabular}

Table 4

Mann-Whitney' U-test for FFM personality traits between each ICC cluster

\begin{tabular}{|c|c|c|c|c|c|c|c|c|c|c|c|c|}
\hline \multirow{2}{*}{$\begin{array}{c}\text { FFM } \\
\text { personality } \\
\text { trait }\end{array}$} & \multicolumn{2}{|c|}{$\begin{array}{c}\text { Cluster } 1- \\
\text { Cluster } 2 \\
\end{array}$} & \multicolumn{2}{|c|}{$\begin{array}{c}\text { Cluster } 1- \\
\text { Cluster } 3 \\
\end{array}$} & \multicolumn{2}{|c|}{$\begin{array}{c}\text { Cluster } 1- \\
\text { Cluster } 4 \\
\end{array}$} & \multicolumn{2}{|c|}{$\begin{array}{c}\text { Cluster } 2- \\
\text { Cluster } 3 \\
\end{array}$} & \multicolumn{2}{|c|}{$\begin{array}{c}\text { Cluster } 2- \\
\text { Cluster } 4 \\
\end{array}$} & \multicolumn{2}{|c|}{$\begin{array}{c}\text { Cluster } 3- \\
\text { Cluster } 4 \\
\end{array}$} \\
\hline & $\mathrm{U}$ & $\mathrm{P}$ & $\mathrm{U}$ & $P$ & $\mathrm{U}$ & $P$ & U & $P$ & U & $P$ & $\mathrm{U}$ & $P$ \\
\hline Neuroticism & 3434 & .647 & 6830,5 & .350 & 6251 & .068 & 3754 & .637 & 3433 & .223 & 6417,5 & .326 \\
\hline Extraversion & 3381 & .776 & 5363 & .039 & 4747,5 & .105 & 2883 & .029 & 2590,5 & .090 & 6096,5 & .769 \\
\hline Openness & 3718,5 & .164 & 6042 & .500 & 4974,5 & .272 & 2917,5 & .037 & 2462,5 & .032 & 5694 & .570 \\
\hline Agreeableness & 3936 & .035 & 6225,5 & .766 & 5444,5 & .984 & 2735,5 & .008 & 2445 & .028 & 6135,5 & .706 \\
\hline Consciousness & 3065 & .453 & 5190,5 & .016 & 4355,5 & .012 & 3145 & .166 & 2625,5 & .115 & 5792 & .721 \\
\hline
\end{tabular}

Note. $p<.05$ is in bold.

Table 4 shows that there are no significant differences in Neuroticism between ICC clusters. This result corresponds to the results of a previous study (Gridunova, Novikova, Shlyakhta 2017), in which no correlation was found between the ICC variables and Neuroticism. The absence of differences between clusters on Neuroticism tells about a lower significance of emotional stability - instability for the ICC manifestation in comparison with other traits.

Extraversion is significantly different between clusters $1-3$ and clusters $2-3$. The representatives of cluster 3 ("Undecided" students) have a slightly higher Extroversion than students who are inclined to absolutize ("Ethnocentrists") and minimize ("Negativists") cultural differences. These results indicate a more pronounced Extroversion in students already in the transition phase to ethnorelativism compared with students who were at ethnocentric stages of ICC development.

Openness is significantly different between clusters $2-3$ and clusters $2-4$ : representatives of cluster 4 ("Ethnorelativists") have maximum, and representatives of cluster 2 ("Negativists") have minimum Openness values. Openness of "Undecided" students (cluster 3 ) is closer to "Ethnorelativists". These data support the importance of Openness for cultural differences acceptance.

Agreeableness differs most strongly between ICC clusters (between clusters 1-2, 2-3, and 2-4). Accordingly, the representatives of cluster 2 ("Negativists") have minimum Agreeableness, and they differ from the representatives of the other groups. This may indicate the lack of tendency to trust others, to seek to support them and show empathy in students, not reckoning with intercultural differences in the interaction process. 
Consciousness is significantly different between clusters $1-3$ and clusters $1-4$ : representatives of cluster 1 ("Ethnocentrists") have minimum Consciousness, while representatives of cluster 4 ("Ethnorelativists") have maximum Consciousness. This data supports the importance of Consciousness, as well as Openness, for cultural differences acceptance. But, at the same time, if low Openness is a characteristic of students who tend to minimize cultural differences ("Negativists"), then the low Conscientiousness is a characteristic of students who tend to absolutize cultural differences ("Ethnocentrists").

\section{Conclusions}

Thus, the research results allowed us to give the brief characteristics of students with different ICC profiles.

The group of "Ethnocentrists" includes 108 people (27.83\% of the sample). These students have the lowest rates of Acceptance and Minimization, but high rates of Absolutization of cultural differences. They differ from representatives of other groups by minimum Consciousness. Students of this group tend to consider intercultural differences as absolute and uncontrollable.

The smallest group of "Negativists" includes 61 students (15.72\% of the sample). They have the lowest rates of Absolutization and Ambivalence, but the highest rates of Minimization. At the same time, they differ from representatives of other groups by the minimum Openness and Agreeableness. The representatives of this group tend to minimize the intercultural difference and consider it insignificant.

The largest group of "Undecided (Ambivalent)" students includes 118 people (30.41\% of the sample). They have the highest rates of Absolutization and Ambivalence, as well as high Acceptance. They have maximum Extraversion and Agreeableness, while on personal traits they are most different from "Negativists" and practically do not differ from "Ethnorelativists". The representatives of this group are in transition from ethnocentrism to ethnorelativism. It is confirmed both by the characteristics of the ICC profiles and personal traits.

The group of "Ethnorelativists" includes 101 students (26.04\% of the sample). They have the highest rates of Acceptance and low Absolutization. And also they have a maximum of Openness and Consciousness. The representatives of this group are most likely to accept cultural differences and take them into account in the interaction.

Thus, the results of the study confirm the presence of profiles, characterized by a different ratio of ICC variables and the severity of FFM personality traits. Also, the study confirmed the importance for ICC development of all FFM personality traits, except of Neuroticism, and above all Openness and Consciousness.

The practical significance of the results is the possibility to develop special programs to improve intercultural competence in Russian universities students based on the identified typological specificity of ICC profiles. In addition, the identification of ICC profiles can be a theoretical basis for the development of new methods of the ICC diagnostics using not only self-assessment questionnaires of certain personal features, but other techniques as well.

The research limitations, first of all, are related to the size and composition of the sample. In the future, we are planning to include students from other universities and fields of the study in the sample. Secondly, it is clear that there are many factors affecting 
ICC, not considered in this work, but needed to build more holistic profiles of ICC. So, as perspectives for further work we intend the extension of the studied characteristics of ICC profiles and the inclusion in the analysis of such psychological characteristics as ethno-national attitudes and intellectual development indicators (in particular, one of the emotional intelligence aspects - the ability to non-verbal behavior interpretation).

\section{Acknowledgments}

The study was carried out as part of the Research Initiative Project No 050421-0-000 "Personality Self-Realization in a Multicultural Environment" at the Social and Differential Psychology Department of RUDN University.

\section{REFERENCES}

Anderson, P.H., Lawton, L., Rexeisen, R.J., \& Hubbard, A.C. (2006). Short-term study abroad and intercultural sensitivity: A pilot study. International Journal of Intercultural Relations, 30, 457-469. doi: $10.1016 /$ j.ijintrel.2005.10.004

Bennett, M.J. (1986). A developmental approach to training for intercultural sensitivity. International Journal of Intercultural Relations, 10, 179-196.

Bennett, M.J. (1993). Towards Ethnorelativism: A Developmental Model of Intercultural Sensitivity. In Paige M. (Eds.) Education for the Intercultural Experience (pp. 21-71). Yarmouth, ME: Intercultural Press.

Bodunov, M.V., \& Biryukov, S.D. (1989). Big 5: Five-Factor Inventory. Adapted and reproduced by special permission of the Publisher, Psychological Assessment Resources from the NEO Five Factor Inventory by P. Costa, R. McCrae. Form S. Moscow: RAS.

Borghetti, C. (2013). Considerations on dynamic assessment of intercultural competence. Diversity, plurilingualism and their impact on language testing and assessment. TEASIGConference Proceedings (pp. 17-20). Siena.

Byram M. (1997). Teaching and assessing intercultural communicative competence. Clevedon: Multilingual Matters.

Chernyak, N.V. (2015). Klassifikatsii modelei mezhkul'turnoi kompetentnosti. Almanac of modern science and education, (2), 119-125. (in Russian).

Chibisova, M., \& Khukhlaev, O. (2008). Measuring teachers' intercultural competence: Towards a theory-based instrument. Book of Abstracts of the 19th International Congress of the International Association for Cross-Cultural Psychology (pp. 237-238). Bremen.

Costa, P.T., \& McCrae, R.R. (1992). Revised NEO Five Factor Inventory (NEO-PI-R) and the NEO Five-Factor Inventory (NEO-FFI). Professional manual. Odessa, FL: Psychological Assessment Resources.

Deardorff, D.K. (2006). Identification and assessment of intercultural competence as a student outcome of internationalization. Journal of Studies in Intercultural Education, 10, 241-266. doi: $10.1177 / 1028315306287002$.

Gridunova, M.V., Novikova, I.A., \& Shlyakhta, D.A. (2017). Intercultural competence and the factors of the "Big five": the formulation of the problem. Izv. Saratov Univ. (N. S.), Ser. Educational Acmeology. Developmental Psychology, 6 (2), 140-148. (in Russian). doi: 10.18500/2304-97902017-6-2-140-147. (In Russ.).

Gridunova, M.V., Novikova, I.A., Radoev, M., \& Shlyakhta, D.A. (2017). The relation between intercultural competence, personality features and students' intellectual development). Journal of the Institute for Educational Research, 49(1), 77-98. doi: 10.2298/ZIPI1701077G. (in Serbian). 
Hammer, M.R., Bennett, M.J., \& Wiseman, R. (2003). Measuring intercultural sensitivity: The Intercultural Development Inventory. International Journal of Intercultural Relations, 27, 421-443. doi: 10.1016/S0147-1767(03)00032-4

Huang, T., Chi, S., \& Lawler, J.J. (2005). The relationship between expatriates' personality traits and their adjustment to international assignments. International Journal of Human Resource Management, 16(9), 1656-1670. doi: 10.1080/09585190500239325.

Kehl, K. \& Morris, J. (2007-2008). Differences in global-mindedness between short-term and semester-long study abroad participants at selected private universities. Frontiers: The Interdisciplinary Journal of Study Abroad, 15, 67-79. Retrieved from http://www.frontiersjournal.com/ frontiersjournal.comissuesvol15index.htm (accessed 17 January 2017).

Khukhlaev, O.E., Chibisova, M.Y. (2010). Theoretical and practical issues of intercultural communication: current trends. Psychological science and education, 5, 168-179.

Kornilova, M.V. (2012). The dynamics of intercultural competence in mono- and multicultural groups (based on the intercultural training) (Ph.D. thesis). Moscow: Moscow City Psychological-Pedagogical University (in Russ.).

Krupnov, A.I., Novikova, I.A., Vorobyeva, A.A. (2016). On the problem of relation between the SystemFunctional and The Five-Factor models of personality traits. Bulletin of Peoples' Friendship University of Russia. Series: Psychology and Pedagogics, (2), 45-56. (In Russ.).

Logashenko, Y.A. (2014). Sensitivity to cultural differences among students with different experiences of intercultural interaction. The Bulletin of Immanuel Kant Baltic Federal University, (11), 73-81. (In Russ.).

Logashhenko, Y.A. (2015). Mezhkul'turnaja sensitivnost'studentovv polijetnicheskoj srede: Ph.D. thesis. St. Petersburg: Saint Petersburg State University. (in Russ.).

Murzakanova, A.Z. (2015). Specifics of Relation between Tolerance and Personality Traits in Russian and Circassian Students. Bulletin of Peoples' Friendship University. Series: Psychology and Pedagogics, (4), 57-64 (in Russ.).

Novikova, I.A., Novikov, A.L., Obidina, N.V. \& Shlyakhta, D.A. (2016). Psychological Predictors of Managerial Performance in the Conditions of Instability of the Russian Economy. International Journal of Environmental and Science Education, 11(18), 10863-10874.

Pochebut, L. G. (2012). Theory of intercultural communicative competence. Nukov Pratsi. Sociology, 184 (172), 14-18. (in Russ.).

Pochebut, L., Logashenko Y. (2014). An intercultural sensitivity as a professional trait of specialists of humanitarian sphere. Society, Integration, Education: Proceeding of the International Scientific Conference (vol. 1, pp. 207-216). Rezekne: Rezekne Higher Education Institution.

R Core Team (2016). R: A Language and Environment for Statistical Computing. Vienna: R Foundation for Statistical Computing.

Revelle, W. \& Zinbarg, R.E. (2009). Coefficients alpha, beta, omega and the glb: comments on Sijtsma. Psychometrika, 74 (1), 145-154.

Rexeisen, R. J. \& Al-Khatib, J. (2009). Assurance of learning and study abroad: A case study. Journal of Teaching in International Business, 20, 192-207. doi: 10.1080/08975930903099077

Sinicrope, C., Norris, J., \& Watanabe Y. (2007). Understanding and assessing intercultural competence: a summary of theory, research and practice. Second Language Studies, 26 (1), 1-58.

Skopinskaja L. (2009). Assessing intercultural communicative competence: test construction issues. Synergies Pays Riverains de la Baltique, 6, 135-144.

UNESCO. (2013). Intercultural competences: Conceptual and Operational Framework. Paris: UNESCO. Available from: unesdoc.unesco.org/images/0021/002197/219768e.pdf. (accessed 20 December 2016). 
Van der Zee, K.I., \& Van der Gang, I. (2007). Personality, threat and effective responses to cultural diversity. European Journal of Personality, 21, 453-470.

Van der Zee, K.I., \& Van Oudenhoven, J.P. (2013). Culture shock or challenge? The role of personality as a determinant of intercultural competence. Journal of Cross-Cultural Psychology, 44, 928-940. doi: $10.1177 / 0022022113493138$

Van der Zee, K.I., \& Van Oudenhoven, J.P. (2014). Personality and multicultural effectiveness. In BenetMartínez V., Hong Ying-Yi (Eds.) The Oxford handbook of multicultural identity (pp. 255-275). New York, NY, US: Oxford University Press.

Yeke S., Semerciöz F. (2016). Relationship between personality traits, cultural intelligence and intercultural communication competence. Procedia - Social and Behavioral Sciences, 235, 313319. doi: 10.1016/j.sbspro.2016.11.036.

(C) Novikova, I.A., Novikov, A.L., Gridunova, M.V., Zamaldinova, G.N., 2017

\title{
Article history:
}

Received 20 March 2017

Revised 28 June 2017

Accepted 30 June 2017

\section{For citation:}

Novikova, I.A., Novikov, A.L., Gridunova, M.V., Zamaldinova, G.N. (2017). Intercultural Competence Profiles in Russian University Students. RUDN Journal of Psychology and Pedagogics, 14 (3), 326-338. DOI 10.22363/2313-1683-2017-14-3-326-338

\section{Bio Note:}

Irina A. Novikova - Ph.D. in Psychology, Associate Professor, Associate Professor of the Social and Differential Psychology Department of Peoples' Friendship University of Russia (Moscow, Russia). E-mail: Novikova_ia@rudn.university

Alexey L. Novikov - Ph.D. in Philology, Associate Professor, Associate Professor of the General and Russian Linguistics Department of Peoples' Friendship University of Russia (Moscow, Russia). E-mail: Novikov_al@rudn.university

Marina V. Gridunova - Postgraduate Student of the Social and Differential Psychology Department of Peoples’ Friendship University of Russia (Moscow, Russia). E-mail: 1042140174@rudn. university

Gulnara N. Zamaldinova - Ph.D. in Psychology, Associate Professor of the Department of Social Sciences and Technologies of National University of Science and Technology MISiS (Moscow, Russia). E-mail: rasgut@yandex.ru

\section{ПРОФИЛИ МЕЖКУЛЬТУРНОЙ КОМПЕТЕНТНОСТИ РОССИЙСКИХ СТУДЕНТОВ}

\author{
И.А. Новикова ${ }^{1}$, А.Л. Новиков ${ }^{1}$, М.В. Гридунова ${ }^{1}$, Г.Н. Замалдинова ${ }^{2}$ \\ ${ }^{1}$ Российский университет дружбы народов \\ ул. Миклухо-Маклая, 6, Москва, Россия, 117198 \\ Национальный исследовательский технологический университет «МИСиС» \\ Ленинский пр., 4, Москва, Россия, 119049
}


Статья посвящена проблеме исследования межкультурной компетентности (МКК) как психологического феномена: ее моделей, факторов, профилей. Представлены результаты эмпирического исследования студентов двух крупных многонациональных российских университетов (388 человек, 254 девушки и 134 юноши), целью которого было выявление типологических профилей МКК и их характеристика в соотношении с индивидуально-личностными факторами. МКК изучалась на основе «Динамической модели межкультурной сенситивности» М. Беннета, для диагностики использовалась модифицированная «Шкала межкультурной сенситивности» О.Е. Хухлаева и М.Ю. Чибисовой в адаптации Ю.А. Логащенко. Индивидуально-личностные факторы рассматривались в рамках Пятифакторной модели Р. Косты и П. МакРэя и диагностировались с помощью краткой формы «Пятифакторного опросника» (русская адаптация М.В. Бодунова и С.Д. Бирюкова). Были выявлены 4 профиля МКК студентов, которым даны условные названия: «этноцентристы», «негативисты», «неопределившиеся (амбивалентные)» и «этнорелятивисты». Показано, что профили различаются между собой не только по характеру соотношения выраженности параметров МКК, но и индивидуально-личностных факторов. Результаты могут быть использованы для разработки программ развития и формирования МКК с учетом выявленной психологической специфики ее профилей.

Ключевые слова: межкультурная компетентность, межкультурная сенситивность, профили межкультурной компетентности, индивидуально-личностные факторы, черты личности, пятифакторная модель

\section{Благодарности и финансирование}

Исследование выполнено в рамках реализации инициативной НИР № 050421-0-000 «Самореализация личности в поликультурной среде» на базе кафедры социальной и дифференциальной психологии Российского университета дружбы народов.

(С) Новикова И.А., Новиков А.Л., Гридунова М.В., Замалдинова Г.Н.., 2017

\section{История статьи:}

Поступила в редакцию: 20 марта 2017

Принята к печати: 30 июня 2017

\section{Для цитирования:}

Новикова И.А., Новиков А.Л., Гридунова М.В., Замалдинова Г.Н. Профили межкультурной компетентности российских студентов // Вестник Российского университета дружбы народов. Серия: Психология и педагогика. 2017. Т. 14. № 3. С. 326-338. DOI 10.22363/23131683-2017-14-3-326-338

\section{Сведения об авторах:}

Новикова Ирина Александровна - кандидат психологических наук, доцент, доцент кафедры социальной и дифференциальной психологии Российского университета дружбы народов (Москва, Россия). E-mail: Novikova_ia@rudn.university

Новиков Алексей Львович - кандидат филологических наук, доцент, доцент кафедры общего и русского языкознания Российского университета дружбы народов (Москва, Россия). E-mail: Novikov_al@rudn.university

Гридунова Марина Владимировна - аспирант кафедры социальной и дифференциальной психологии Российского университета дружбы народов (Москва, Россия). E-mail: 1042140174@rudn.university

Замалдинова Гульнара Нуровна - кандидат психологических наук, доцент кафедры социальных наук и технологий Национального исследовательского технологического университета «МИСиС» (Москва, Россия). E-mail: rasgut@yandex.ru 